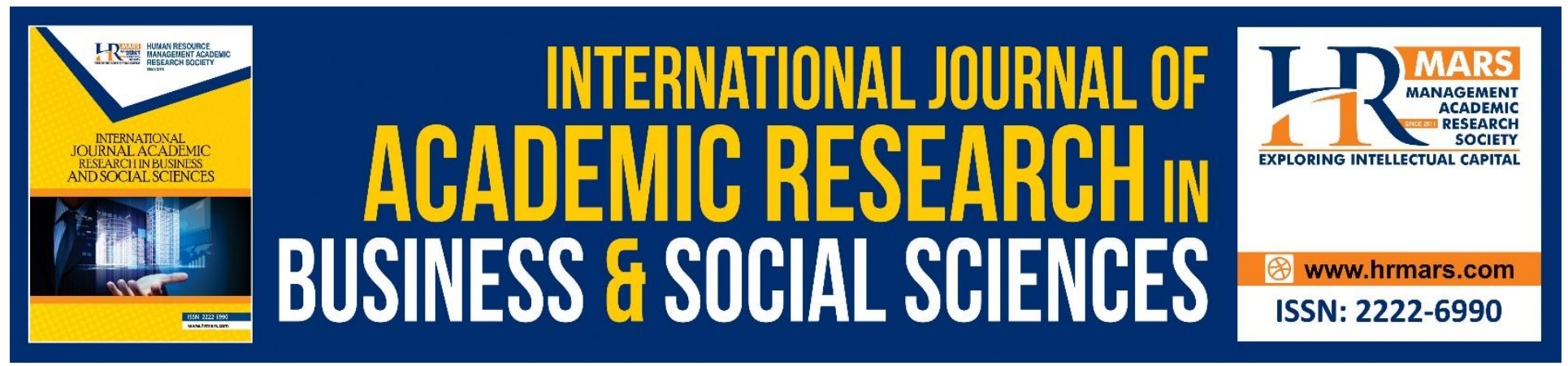

\title{
Influence of Employee Assistance Programs on Commitment of Nurses in Public Hospitals in Kenya
}

Denis Okerosi Okemwa, Wallace Nyakundi Atambo, Willy Mwangi Muturi

To Link this Article: http://dx.doi.org/10.6007/IJARBSS/v9-i1/5376

DOI: $\quad 10.6007 /$ IJARBSS/v9-i1/5376

Received: 29 Dec 2018, Revised: 17 Jan 2019, Accepted: 24 Jan 2019

Published Online: 28 Jan 2019

In-Text Citation: (Okemwa, Atambo, \& Muturi, 2019)

To Cite this Article: Okemwa, D. O., Atambo, W. N., \& Muturi, W. M. (2019). Influence of Employee Assistance Programs on Commitment of Nurses in Public Hospitals in Kenya. International Journal of Academic Research in Business and Social Sciences, 9(1), 151-164.

Copyright: (C) 2019 The Author(s)

Published by Human Resource Management Academic Research Society (www.hrmars.com)

This article is published under the Creative Commons Attribution (CC BY 4.0) license. Anyone may reproduce, distribute, translate and create derivative works of this article (for both commercial and non-commercial purposes), subject to full attribution to the original publication and authors. The full terms of this license may be seen

at: http://creativecommons.org/licences/by/4.0/legalcode

Vol. 9, No. 1, 2019, Pg. 151 - 164

http://hrmars.com/index.php/pages/detail/IJARBSS

JOURNAL HOMEPAGE

Full Terms \& Conditions of access and use can be found at http://hrmars.com/index.php/pages/detail/publication-ethics 


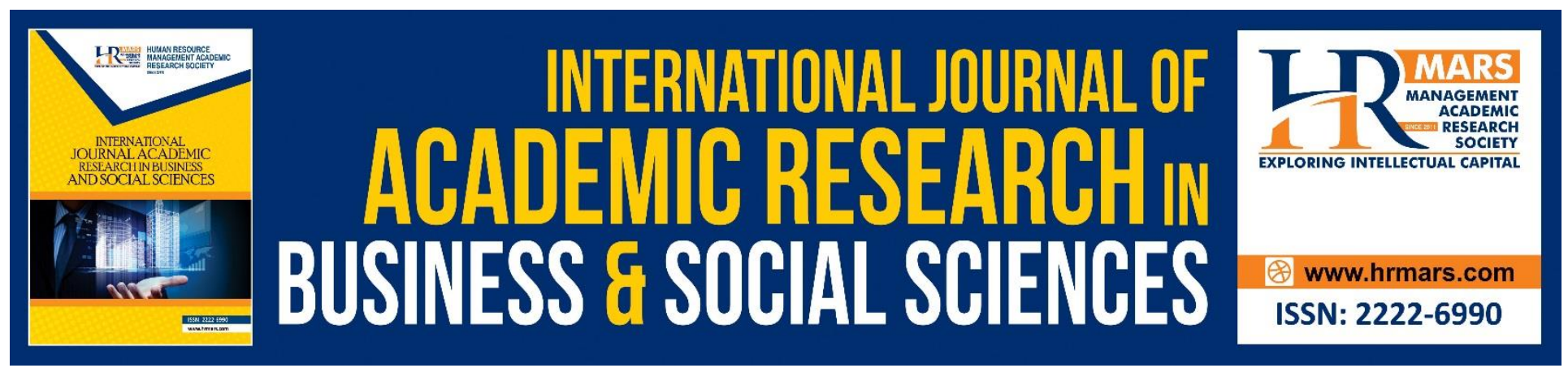

\title{
Influence of Employee Assistance Programs on Commitment of Nurses in Public Hospitals in Kenya
}

\author{
Denis Okerosi Okemwa \\ PhD Candidate, Jomo Kenyatta University of Agriculture and Technology \\ Corresponding Author Email: denisokemwa2@gmail.com \\ Dr. Wallace Nyakundi Atambo \\ Jomo Kenyatta University of Agriculture and Technology \\ Prof. Willy Mwangi Muturi \\ Jomo Kenyatta University of Agriculture and Technology
}

\begin{abstract}
The aim of this study was to investigate the influence of employee assistance programs on commitment of nurses in public hospitals in Kenya. Specifically, the study was guided by the hypothesis; Employee assistance program has no significant influence on commitment of nurses in public hospitals in Kenya. The researcher utilized proportionate simple random sampling to select 364 nurses. A cross sectional research design was used. Semi-structured questionnaires were used to collect data. Data were analysed using descriptive and inferential statistics. The findings suggest that there is a weak positive correlation between employee assistance programs and level of commitment of the nurses as indicated by a Pearson's correlation coefficient of 0.394 significant at $5 \%$ level of significance. Secondly, the regression model on the influence of employee assistance programs on commitment of nurses; commitment=26.304+0.620(adequacy of Employee Assistance Programs), indicating that there is a positive linear relationship between employee assistance and commitment. Fourthly, $t$-test values and $f$ - test values $(t=7.516, p<0.05) ; f=54.495, p<0.05)$ indicated that employee assistance programs had a statistically significant effect on the level of commitment of the nurses. In addition, coefficient of determination $R^{2}=0.155$, indicating that $15.5 \%$ of the variation in the level of commitment for the sample of 309 nurses in public hospitals can be explained by the variations in the adequacy of employee assistance programs. Based on these findings, the researcher concludes that adequacy of employee assistance programs significantly influences levels of commitment of nurses in public hospitals in Kenya. Given that employee assistance programs in public hospitals is inadequate the study recommends that public hospital management team should enhance
\end{abstract}


INTERNATIONAL JOURNAL OF ACADEMIC RESEARCH IN BUSINESS AND SOCIAL SCIENCES Vol. 9, No. 1, Jan, 2019, E-ISSN: 2222-6990 (C) 2019 HRMARS

employee assistance programs in terms of adequacy in order to improve on the levels of commitment of nurses. The researcher Suggests a further research on the influence of employee assistance programs on commitment of nurses' in faith-based health and private hospitals in Kenya.

Keywords: Influence, Employee Assistance Programs, Commitment, Nurses, Public Hospitals.

\section{INTRODUCTION}

In today's globalized environment organizations are facing new and intense challenges regarding continuous improvements in quality service and creating and sustaining a committed human resource. Presently, neither product nor service provision organization can perform at highest quality levels unless each and single employee is committed to the realization of organizations goals and objectives (Dixit \& Bhati, 2012). The great interest in commitment in organizations is due to increase in strained relationships between employees and their organizations due work-life conflict as well as an unapologetic demand by contemporary clients for quality service. Therefore, it is imperative to note that for organizations to build on efficiency and gain competitive advantage it must invest in management practices that enhance commitment of employees (Lissy \& Ventakash, 2014). A committed employee has the desire to remain loyal to the organization, attends work regularly, protects company's assets, shares company's goals and invests his/her all in the organization among other tasks (Fabiene \& Kachchhap, 2016). Thus commitment could be referred to as glue that binds a person towards an object, a goal or a role (Armstrong, 2009). To promote commitment among workers employers, organizations strive to provide adequate employee assistance programs that match with specific needs of workers.

Osterman (2001) observes that employee assistance programs are institutionalized structural and procedural arrangements as well as formal and informal practices that enable individuals to easily manage the conflicting worlds of work and family/personal. In this study employee assistance programs are considered as a set of the human resources management practices devoted to enhancing employee balance among work, personal and family demands of life thereby raising their commitment levels. Enemuo (2016) agrees with Osterman (2001) that employee assistance programs undertake to harmoniously enable individuals perform multiple roles of work and life. Organizations can implement various employee assistance programs that may enable employees to better balance their work and family responsibilities, gain improvements in well-being, and provide organizational benefits.

\section{STATEMENT OF THE PROBLEM}

Achieving appropriate equilibrium between work-life and personal or family life has for a long time been one of the challenges experienced by nurses in public hospitals in Kenya (Chankova, Muchiri \& Kombe, 2009). When nurses are more involved in their job than their non -work demands results to higher the work-family conflict which eventually leads to low job satisfaction and reduced commitment. Fabiene and Kachchhap (2016); Akacho (2014) and Al-Hassumi (2008) observed that health care organizations are constrained with low commitment of health care professionals and this greatly affects the quality of service delivery. It is understood that employee assistance programs as one of the work-life balance initiatives play a phenomenal role in combining work and non-work 
INTERNATIONAL JOURNAL OF ACADEMIC RESEARCH IN BUSINESS AND SOCIAL SCIENCES

Vol. 9, No. 1, Jan, 2019, E-ISSN: 2222-6990 (C) 2019 HRMARS

demands (Muchiti \& Gachunga, 2015). The study therefore was set out to investigate the influence of employee assistance programs on commitment of nurses in public hospitals Kenya.

\section{HYPOTHESIS OF THE STUDY}

$\mathbf{H}_{\mathrm{o1}}$ : There is no significant influence of employee assistance programs on commitment of nurses in public hospitals in Kenya.

\section{CONCEPTUAL FRAMEWORK}

The conceptual framework in this study shows the link of the variables of study; employee assistance programs and employee commitment. The dependent variable is employee commitment which has three components; affective commitment, normative commitment and continuance commitment. The two indicators of employee assistance programs were professional counselling and medical insurance. This is shown in figure 1a

\begin{tabular}{|l|l|}
\hline $\begin{array}{l}\text { Employee Assistance } \\
\text { Programs. }\end{array}$ & $\begin{array}{l}\text { Commitment } \\
\text { - Professional } \\
\text { Counselling } \\
\text { Medical insurance }\end{array}$ \\
\hline & - Affective \\
& \\
\hline
\end{tabular}

Figure 1a: Influence of Employee Assistance Programs on Commitment

\section{EMPLOYEE ASSISTANCE PROGRAMS}

Employee Assistance Programs are workplace programs designed to address problems that negatively affect employees' well-being. They are "job-based programs operating within a work organization for the purposes of identifying 'troubled employees,' motivating them to resolve their troubles, and providing access to counselling or treatment for those employees who need these services (Martin \& Roman 2004). Muli (2014) supports the above view by Martin \& Romans (2004) and holds that employee assistance programs are work-life balance interventions designed to address problems that negatively affect employees' wellbeing. Further, Carrel et al., (1989) asserts that employee assistance programs are introduced by employers as a humanitarian and moral act to assist employees to cope with work place demands and to overcome the difficulties that are related to work. In addition, Cascio (2003) asserts that employee assistance programmes are comprehensive management tools that address behavioural risks in the workplace by extending professional counselling and medical services to all "troubled employees.

\section{COMMITMENT}

Commitment is the relative strength of the individuals' identification with, and involvement in a particular organization (Matheus \& Zajac, 2003). It mainly consists of a strong desire to remain a member of the organization, acceptance of the goals of the organization, core values and a readiness 
to exert effort on behalf of the organization (Armstrong, 2009). Employee commitment is a psychological state that characterizes the employee's relationships with the organization and has implications for the decision to continue membership in the organization (Meyer, Stanley \& Herscovitch, 2002).

Meyer and Allen (1991) developed a three-component model of commitment measuring affective, continuance and normative commitment components. They observed that affective commitment refers to the employee's emotional attachment to, identification with and involvement in the organization. An affectively committed employee beliefs in and accepts organization goals and values, has willingness to focus effort on helping the organization achieve her goals and desire to maintain organizational membership. Some of the behaviour often exhibited by affectively committed employees include desire to remain with the organization, high level performance, lower rate of absenteeism, advancement and growth. Continuance commitment refers to an awareness of the costs associated with leaving the organization. The researchers reveal that an employee who has continuance commitment have willingness to remain in an organization because of non-transferrable investments which include among others; relationships with other employees or other things that are special to the organization. An employee who has continuance commitment was find it very difficult to leave the organization to avoid losing such investments. Normative commitment reflects a feeling of obligation to continue employment. The researchers' revealed that high level of normative commitment in employees create a feeling that they ought to remain with the organization because of moral obligation. Employee assistance programs is a pivotal factor on commitment. The feeling of commitment increases among the employee due to level of care and appreciation at work. Employee assistance programs creates a perception in employees of being valued and cared for which invariably strengthens commitment to the institution. It has also been established in the study that employee assistance programs increase feeling of wholeness, harmony and wellbeing, due to the level of care and appreciation at work (Gray and Jacqueline, 2003).

\section{INFLUENCE OF EMPLOYEE ASSISTANCE PROGRAMS ON COMMITMENT}

Azeem and Akhtar (2014) investigated the influence of employee assistance programme on organization commitment of health care workers in Ghana. The study revealed that low commitment and poor productivity were associated with poor implementation of employee assistance programmes. The researcher concluded that efficient and effective implementation of employee assistance programmes is imperative for inducing employee commitment. Ojo (2012) examined the extent to which employee assistance programmes affect employee commitment. The study revealed that employee assistance programmes enabled employee commitment. The researcher concluded that employee assistance programmes reduces absenteeism and promotes good working relationship between management and workers.

Kamau, Muleke, Mokaya and Wagoki (2013) study on Work-life balance and employee job performance at Eco bank, Kenya. The study revealed that employee assistance programmes such as employee health programs keep workforce healthy, improves the social welfare, improved attendance rates, and eliminates worries thereby making them to contribute always to the organization. The study affirms that there is a significant positive relation between employee 
INTERNATIONAL JOURNAL OF ACADEMIC RESEARCH IN BUSINESS AND SOCIAL SCIENCES Vol. 9, No. 1, Jan, 2019, E-ISSN: 2222-6990 @ 2019 HRMARS

assistance programs and performance. The researcher observes that employee assistance programmes enabled employees to secure high quality dependent care services and also provide an avenue to which they can focus on their jobs while at work and expect positive outcomes in content delivery of their work.

Mwangi, Boinett, Tumwet and Bowen (2017) in the study on effects of work-life balance on employees' performance in institutions of higher learning, revealed that employee assistance programs have a significant influence on employee performance in institutions of higher learning. One of the specific objectives of the study was to establish the effect of employee assistance programs on employee performance. The study adopted case study research design. Questionnaires formed the primary data collection tool. The target population was 244 from which a sample size of 70 was generated. The researchers observed that employee assistance programmes create a good avenue for an organization to extend a helping hand to individual workers and this impact positively on staff commitment. The study concluded that employee assistance programmes is an important tool for inducing the needed commitment for greater productivity.

Fapohunda (2014) explored the effect of employee assistance programs on employee commitment to corporate productivity in China. 200 respondents in the health sector were used for the survey. The study revealed that employee assistance programs creates an opportunity for an organization to extend a helping hand to individual worker and this impact positively on employee commitment to institutional objective. The researcher concluded that employee assistance programs are crucial in enhancing employee's commitment for quality service.

Wainaina (2015) examined the relationship between work-life balance practices and organizational commitment among the academic staff in the public and private universities in Kenya. The study adopted a cross sectional survey design. The study targeted population was all academic staff in public and private universities in Kenya. Stratified sampling was used to select sixteen universities followed by simple random sampling to select both representative department and staff from selected departments. 347 academic staff formed the sample for the study. Questionnaire formed the primary data collection tool. The study revealed that there was positive but weak relationship between work-life balance practices and organizational commitment.

Much of the studies reviewed had been done outside Kenya and had not focused on the influence of employee assistance programs on commitment of nurses but to a small extend. Therefore, there is need to hold a study on the influence of work-life balance initiatives on commitment of nurses to fill this research void. Researchers in business sector have observed that work-life balance contribute to enhanced commitment, increased business success and competitive advantage for a business (Mungania, 2016; Orogbu, Onyeizugbe \& Chukwuemeke, 2015; Mwebi \& Kadaga, 2015); however, there is a gap in research in health care sector particularly in public healthcare in Kenya on the influence of employee assistance programs on commitment of nurses, hence need for the current study. 


\section{RESEARCH METHODOLOGY}

The study adopted a cross-sectional survey design. Survey was be preferred for its special appeal for generalizability (Mugenda \& Mugenda, 2003). They further argue that survey design is important in explaining or describing data collected from populations that are too large to observe. The researcher used proportionate simple random sampling to select 7 hospitals from 25 hospitals. This formed $28 \%$ of the 25 hospitals in the 5 selected counties. From the 7 hospitals sampled 364 nurses out of 1217 nurses forming $30 \%$ of the total number of nurses were selected through proportionate simple random sampling.

The questionnaire was pilot tested on 36 nurses and 3 hospitals that were part of the target population but not in the sample to determine their reliability. Saunders, Lewis, and Thornhill (2007) recommend a pilot test of between $5 \%$ and $10 \%$ of the study sample. Reliability analysis was carried out to ascertain the internal consistency of the data items using the Cronbach's alpha. The results obtained indicated that the questionnaire was reliable with a Cronbach alpha of .743. After pilot testing, the items in the questionnaires which were ambiguous, repeated, and long were adjusted and revised to incorporate the feedback that was provided and to ensure internal consistent. Validity of the questionnaire on the other hand was ascertained by seeking the comments of supervisors, lecturers and peers on the adequacy of coverage, general agreement from literature, clarity and length of the instrument, spacing of the questionnaire. The recommendations from the Human resource experts, lecturers and peers was used to refine and improve the validity of the questionnaire. Their suggestions helped in removing ambiguities; inadequate terms and this made it possible for the researcher to clarify questions and thereby improve the quality and increase the strength and validity of the research instrument.

\section{RESEARCH FINDINGS}

\section{FACTOR ANALYSIS ON EMPLOYEE ASSISTANCE PROGRAMS}

Factor analysis was done to determine how well the constructs used were measuring the latent variable 'adequacy of employee assistance programs. Results in Table $\mathbf{1 b}$ show that the items in the employee assistance programs and their factor loadings. All the items had a factor loading of more than 0.7 which is considered suitable in measuring the adequacy of employee assistance programs.

Table 1b: Factor loading for Employee Assistance Programs.

\begin{tabular}{lc}
\hline Statement & Factor Loadings \\
\hline Medical insurance enables me to secure high quality dependent care & .887 \\
services. & .915 \\
Medical insurance cover for staff and dependents provided & .927 \\
eliminates my worries about medical expenses. & .903 \\
$\begin{array}{l}\text { Free professional counselling provided enables me to address my } \\
\text { social and psychological challenges. }\end{array}$ & .904 \\
$\begin{array}{l}\text { Professional counselling provided enhances my work attendances. } \\
\text { Professional counselling accords me an avenue to focus on the job }\end{array}$ & \\
\hline while at work. &
\end{tabular}

Extraction Method: Principal Component Analysis.

a. 1 Components extracted. 
INTERNATIONAL JOURNAL OF ACADEMIC RESEARCH IN BUSINESS AND SOCIAL SCIENCES

Vol. 9, No. 1, Jan, 2019, E-ISSN: 2222-6990 (C) 2019 HRMARS

\section{AGGREGATION OF EMPLOYEE ASSISTANCE PROGRAM CONSTRUCTS}

The ratings for each respondent on the various indicators of employee assistance programs were summed up to obtain an index which measured the adequacy of the provided employee assistance programs for nurses in public hospitals in Kenya, the index ranged from 5 to 25. An index of more than 15 could imply that employee assistance programs for the nurses were adequate while an index of less than 15 could imply inadequate employee assistance programs. The descriptive statistics results displayed in Table 1c indicate that employee assistance programs had a mean index of 14.3528 with the scores deviating by 6.33188 from the mean score. Since the mean was less than the average score of 15 , the result suggest that the employee assistance programs were inadequate. This implies that nurses in public hospitals have to dig deeper into their pockets to seek specialized and quality medical attention for themselves and dependents from elsewhere among other employee assistance services.

Table 1c: Aggregation of the employee assistance programs Indices

\begin{tabular}{lrcccc}
\hline & $\mathrm{N}$ & Minimum & $\begin{array}{c}\text { Maximu } \\
\mathrm{m}\end{array}$ & Mean & Std. Deviation \\
& Statistic & Statistic & Statistic & Statistic & Statistic \\
\hline $\begin{array}{l}\text { Employee } \\
\text { Assistance }\end{array}$ & 309 & 5.00 & 25.00 & 14.3528 & 6.33188 \\
$\begin{array}{l}\text { Programs } \\
\text { Valid N }\end{array}$ & & & & & \\
(listwise) & 309 & & & & \\
\hline
\end{tabular}

\section{CORRELATION BETWEEN EMPLOYEE ASSISTANCE PROGRAMS AND LEVEL OF COMMITMENT}

The Pearson's correlation coefficient was used to measure the nature and strength of the relationship between employee assistance programs and level of Commitment among the nurses in public hospitals. Table $1 \mathbf{d}$ results of correlation analysis show a weak positive relationship between employee assistance programs and level of commitment of the nurses as indicated by a Pearson's correlation coefficient of 0.394 significant at $5 \%$ level of significance. Indicating that the level of commitment of nurses will significantly increase when the adequacy of employee assistance services is also enhanced. 
INTERNATIONAL JOURNAL OF ACADEMIC RESEARCH IN BUSINESS AND SOCIAL SCIENCES Vol. 9, No. 1, Jan, 2019, E-ISSN: 2222-6990 @ 2019 HRMARS

Table 1d. Correlation Results: Influence of Leave Arrangements on Commitment of Nurses

\begin{tabular}{llcc}
\hline & & $\begin{array}{c}\text { Employee } \\
\text { assistance } \\
\text { Programs }\end{array}$ & Commitment \\
Employee & Pearson Correlation & 1 & $.394^{* *}$ \\
Assistance & Sig. (2-tailed) & 309 & .000 \\
Programs & $\mathrm{N}$ & $.394^{* *}$ & 309 \\
& Pearson Correlation & & 1 \\
Commitment. & Sig. (2-tailed) & .000 & \\
& $\mathrm{~N}$ & 309 & 309 \\
\hline
\end{tabular}

**. Correlation is significant at the 0.01 level (2-tailed).

\section{SIMPLE LINEAR REGRESSION ANALYSIS ON THE INFLUENCE OF EMPLOYEE ASSISTANCE PROGRAMS ON COMMITMENT OF NURSES IN PUBLIC HOSPITALS IN KENYA.}

To establish the influence of employee assistance programs on Commitment, a simple linear regression analysis was used. The regression model was of the form:

$$
Y=\beta_{0}+\beta_{1} X_{1}+\epsilon, \quad \epsilon \sim N(0,1)
$$

Where, $Y$ is the Level of Commitment; $X_{1}$ is the adequacy of the employee assistance programs, $\beta_{0}$ is the constant of the regression equation, $\beta_{1}$ is the regression coefficient and $\epsilon$ is the error component. Based on the regression coefficients in Table $\mathbf{e}$, the regression model for the influence of employee assistance programs on commitment of nurses in public hospitals in Kenya is therefore;

Nurses'level of Commitment $=26.304+0.620 *$ (Employee assistance programs The regression model further confirms that the there is a positive and linear relationship between employee assistance programs and commitment of nurses in public hospitals in Kenya. It shows that a \% unit increase in adequacy of employee assistance programs improves the level of commitment of nurses by $0.62 \%$.

The results illustrated in Table e further indicates that the t-test values for the employee assistance $(t=7.516, p<0.05)$. Since $p(0.00)$ is less than alpha $(0.05)$ it shows that employee assistance programs significantly influence commitment of nurses in public hospitals in Kenya. On the basis of these results, the study rejected the null hypothesis that 'employee assistance programs had no statistically significant effect on the level of commitment among the nurses in public hospitals Kenya' and conclude that employee assistance programs has a statistically significant effect on the level of commitment among the nurses in public hospitals Kenya. 
INTERNATIONAL JOURNAL OF ACADEMIC RESEARCH IN BUSINESS AND SOCIAL SCIENCES

Vol. 9, No. 1, Jan, 2019, E-ISSN: 2222-6990 (C) 2019 HRMARS

Table 1e: The coefficients of the Regression Model of Employee Assistance Programs and Commitment.

\begin{tabular}{|c|c|c|c|c|c|c|}
\hline \multirow{2}{*}{\multicolumn{2}{|c|}{ Model }} & \multicolumn{2}{|c|}{$\begin{array}{l}\text { Unstandardized } \\
\text { Coefficients }\end{array}$} & \multirow{2}{*}{$\begin{array}{c}\text { Standardized } \\
\text { Coefficients } \\
\text { Beta }\end{array}$} & \multirow[t]{2}{*}{$\mathrm{t}$} & \multirow[t]{2}{*}{ Sig. } \\
\hline & & $\mathrm{B}$ & Std. Error & & & \\
\hline \multirow{3}{*}{1} & (Constant) & 26.304 & 1.515 & & 17.360 & .000 \\
\hline & Employee & .620 & .082 & .394 & 7.516 & .000 \\
\hline & $\begin{array}{l}\text { Support } \\
\text { programs }\end{array}$ & & & & & \\
\hline
\end{tabular}

a. Dependent Variable: Commitment

\section{ANOVA RESULTS ON THE INFLUENCE OF EMPLOYEE ASSISTANCE PROGRAMS ON COMMITMENT OF NURSES}

To further test the significance of variables, ANOVA (F) test statistics were used. The results presented in Table $1 f$ shows that the independent variable (employee assistance programs) can significantly predict the level of commitment among the nurses in public hospitals in Kenya $\left(F_{(1,308)}=54.495, p<\right.$ 0.05). This further confirms the results above that employee assistance programs has a positive and significant effect on the level of commitment of nurses in public hospitals in Kenya.

Table 1f: ANOVA ${ }^{a}$ Results on the Influence of Employee Assistance Programs on Commitment of Nurses in Public Hospitals in Kenya.

\begin{tabular}{|c|c|c|c|c|c|c|}
\hline Model & & $\begin{array}{l}\text { Sum of } \\
\text { Squares }\end{array}$ & Df & $\begin{array}{l}\text { Mean } \\
\text { Square }\end{array}$ & $\mathrm{F}$ & Sig. \\
\hline & Regression & 3805.824 & 1 & 3805.824 & 56.495 & $.000^{b}$ \\
\hline \multirow[t]{2}{*}{1} & Residual & 20681.193 & 307 & 67.365 & & \\
\hline & Total & 24487.016 & 308 & & & \\
\hline
\end{tabular}

a. Dependent Variable: commitment

b. Predictors: (Constant), employee assistance programs

MODEL SUMMARY: INFLUENCE OF EMPLOYEE ASSISTANCE PROGRAMS ON COMMITMENT

To assess the goodness-of-fit of the model, the coefficient of determination $\left(R^{2}\right)$ was established. The results presented in Table $1 \mathrm{~g}$ indicates $\left(\mathrm{R}^{2}\right)=0.155$ suggesting that $15.5 \%$ of the variation in the level of commitment for the sample of 309 nurses in public hospitals can be explained by the variations in the adequacy of employee assistance programs. Based on findings in Table $\mathbf{1 g}$ the study concluded that there was a significant positive relationship between level of commitment and the adequacy of employee assistance programs, suggesting that if nurses' employee assistance programs were made adequate then their level of commitment will consequently be improved. 
INTERNATIONAL JOURNAL OF ACADEMIC RESEARCH IN BUSINESS AND SOCIAL SCIENCES Vol. 9, No. 1, Jan, 2019, E-ISSN: 2222-6990 @ 2019 HRMARS

Table 1g: Model Summary Employee assistance programs

\begin{tabular}{lrrrr}
\hline Model & $\mathrm{R}$ & R Square & Adjusted R Square & \multicolumn{2}{c}{$\begin{array}{c}\text { Std. Error of the } \\
\text { Estimate }\end{array}$} \\
\hline 1 & $.394^{\mathrm{a}}$ & .155 & .153 & 8.208 \\
\hline
\end{tabular}

a. Predictors: (Constant), employee assistance programs

\section{DISCUSSION OF THE RESEARCH FINDINGS}

The objective of the study was to examine the influence of employee assistance programs on commitment of nurses in public hospitals in Kenya. The study established a weak positive correlation coefficient $\mathbf{r}$ of 0.394 , a linear relationship between employee assistance programs and commitment; (Commitment $=26.304+0.62$ (Employee assistance programs), $\mathrm{R}^{2}=.155$ suggesting that $15.5 \%$ of the variation in the level of commitment by the sample of 309 nurses can be explained by the adequacy of employee assistance programs. $t=7.516, p>0.05, F=56.495, p>0.05$ values respectively indicating that employee assistance services significantly influence commitment of nurses in public hospitals in Kenya hence rejection of the null hypothesis that employee assistance programs has no significant influence on commitment of nurses in public hospitals in Kenya.

The findings are in agreement with Kamau, Muleke, Mokaya and Wagoki (2013) results that there is a significant positive relationship between employee assistance programmes and performance. They further observed that employee assistance programs provide an avenue for employees to focus on their jobs while at work and expect positive outcomes in content delivery of their work. Further, Azeem \& Akhtar (2014); Mwangi, Boinett, Tumwet \& Bowen (2017) \& Ojo (2012) observed employee that assistance programs are an important tool for inducing the needed commitment for greater productivity. The finding of the study also provides support for the claim of Fapohunda (2014) that employee assistance program creates an opportunity for an organization to lend a helping hand to individual staff and this greatly impact on employee's commitment to organization goal.

However, a previous research finding of Sakthivel and Selvarania (2012) was in disagreement with the present study. The researchers found a negative effect of employee assistance programmes on employees' commitment. The difference of Sakthivel and Selvarania (2012) empirical evidence with the present study may be due to variances in sample sizes, nature of data and setting of the studies.

\section{SUMMARY OF THE FINDINGS}

The overall objective of this study was to determine the influence of employee assistance programs on commitment of nurses' in public hospitals in Kenya. The descriptive statistics results displayed showed that employee assistance programs had a mean index of 14.3528 with the scores deviating by 6.33188 from the mean score. Since the mean was less than the average score of 15 , the result suggest that the employee assistance programs were inadequate.The study established that there is weak positive relationship between employee assistance programs and level of commitment of the nurses as indicated by a Pearson's correlation coefficient $R$ and a coefficient of determination $R$ square as 0.394 and 0.155 respectively significant at $5 \%$ level of significance. The linear regression equation coefficients $\beta_{0}$ and $\beta_{1}$ were 26.304 and 0.620 respectively suggesting that a $\%$ unit increase 
in adequacy of employee assistance programs improves the level of commitment of nurses by $0.62 \%$. The researcher further established that employee assistance programs had a statistically significant effect on the level of commitment of the nurses $(t=7.516, p<0.05)$ and $f=56.495$ likewise, the constant of the regression model is significant at 0.05 level of significance $(t=17.360, p<0.05$ ), indicating that there is a significant positive relationship between adequacy of employee assistance programs and commitment of the nurses in public hospitals in Kenya. On the strength of this findings the null hypothesis that employee assistance programs have no significant influence on commitment of nurses is thus rejected.

\section{CONCLUSION}

The researcher concludes that adequacy of employee assistance programs significantly influences the levels of commitment of nurses in public hospitals in Kenya. It's further revealed that there is a weak positive and significant linear relationship between employee assistance programs and level of commitment of the nurses.

\section{CONTRIBUTION TO THEORY}

The study revealed that adequacy of employee assistance programs has a positive and significant influence on the levels of commitment of nurses in public hospitals in Kenya. The findings converged with the hypothesized model that employee assistance programs significantly influence on the levels of commitment of nurses in public hospitals in Kenya.

\section{RECOMMENDATIONS}

Based on the findings and the conclusion of this study, the researcher made the following recommendations which will be relevant, not only to the health sectors, but also to the policy makers and practitioners of other sectors in both national and county governments in Kenya. Public hospital management team should enhance the adequacy of employee assistance programs such as comprehensive medical insurance covers or access to free treatment or free counselling, recreational facilities for relaxation in order to enhance the levels of commitment of nurses in public hospitals in Kenya. Given that employee assistance programmes not only benefit the workers in terms of striking a balance between work-life and personal or and family life but it is a veritable tool for inducing levels of commitment of nurses in public hospitals.

\section{SUGGESTION FOR FURTHER RESEARCH}

Examine the influence of employee assistance programs on commitment of nurses' in faith-based health and private hospitals in Kenya.

\section{REFERENCES}

Akacho, E. N. (2014). Factors influencing provision of health care service delivery in Kenya. A case of Uasin Gishu District Hospital in Eldoret. University of Nairobi.

Al- Hassumi. (2008). The relationship between satisfaction, attitudes, and performance: In-dualcareer couples. Human Relations, 3(2), 451-467.

Armstrong, M. (2009). Armstrong's Handbook Of human resource Management practice 11th 
INTERNATIONAL JOURNAL OF ACADEMIC RESEARCH IN BUSINESS AND SOCIAL SCIENCES

Vol. 9, No. 1, Jan, 2019, E-ISSN: 2222-6990 @ 2019 HRMARS

edition . London: Cogan Page Ltd.

Azeem, S.A., \& Akhtar, N. (2014). The influence of Work-life Balance and Job Satisfaction on Organizational Commitment of Health Care Employees. International Journal of Human Resource Studies, 4(2), 18-24.

Cascio, W.F. (2003). Managing human resources: Productivity, quality of work life, profits .(6 ${ }^{\text {th }}$ ed.). New York: McGraw-Hill, Irwin.

Carrell, R. M., Kuzmits, F. E. \& Elbert, N. F. 1989. Personnel: Human Resource Management. Columbus: Merrill Publishing Company.

Chankova, S., Muchiri, S. \& Kombe, G. (2009). Health Workforce Attrition in the Public Sector in Kenya: A Look at the Reasons. Hum Resour Health, 7(58).

Cropanzano, R., Anthony, E.L., Daniels, S.R., Hall, A. V. (2017). Social Exchange Theory: A critical Review with Theoretical Remedies. Academic Management Annals, 11, 479-516.

Dixit, V., \& Bhati, M. (2012). A Study about Employee Commitment and its impact on Sustained Productivity in Indian Auto-Component Industry. European Journal of Business and Social Sciences, 1(6), 34-51.

Enemuo, J. I. U. (2016). Effect of Work-life Balance on Performance of Selected Federal State Health Institutions in South East Nigeria.

Fabiene, E.E., \& Kachchhap, S. L. (2016). Determinants of Employee's Commitment Among Health Care Professionals. International Journal of Academic Research in Accounting Finance and Management Sciences., (2), 44-52.

Fapohunda, T. M. (2014). An exploration of the effects of work-life balance on productivity. Journal of Human Resource Management and Labour Studies, 2(2), 71-89.

Gray, R., \& Jacqueline, T. (2003). Family-friendly work practices: Journal of Industrial Relations, 45(3), 269-291.

Kamau, J.M., Muleke, V., Mokaya, S.O., \& Wagoki, J. (2013). Work-life Balance Practices on Employee Job Performance at Eco Bank Kenya. European Journal of Business and Management, 5(25), 179-185.

Lissy,T.A \& Venkatesh,J. (2014). Factors influencing organizational commitment.A Case of paramedical staff at private Hospitals. International Journal of Multidisciplinary Approach and Studies, Vol.1, No.6.

Martin, J., \& Roman, M. (2004). A research note on EAP prevalence, components and utilization. Journal of Employee Assistance Research, 1(1):209-229.

Mathieu, J. E., \& Zajac, D. M. (1990). A review and meta-analysis of the antecedents, correlates and consequences of organizational commitment. Psychological Bulletin, 108(2), 171- 194.

Meyer, J. P., \& Allen, N. J. (1991). A three-component conceptualization of organizational commitment. Human Resource Management Review, 1, 61-89.

Meyer, J. P., Stanley, D. J., Herscovitch, L., \& Topolnytsky, L. (2002). Affective, continuance, and normative commitment to the organization: A meta-analysis of antecedents, correlates, and consequences. Journal of Vocational Behavior, 61(1), 20-52.

Muchiti, E. \& Gachunga, H. (2015). Influence of Work Life Balance on Employee Productivity in Kenya; A Case of Milimani Law Courts Nairobi. The Strategic Business and Change Journal of Management, 2(48), 1-20. 
INTERNATIONAL JOURNAL OF ACADEMIC RESEARCH IN BUSINESS AND SOCIAL SCIENCES

Vol. 9, No. 1, Jan, 2019, E-ISSN: 2222-6990 (C) 2019 HRMARS

Mugenda, O. M. \& Mugenda, A. G. (2003). Research Methods: Quantitative and Qualitative. Approaches. Nairobi: ACTS.

Mungania, A. K. (2017). Influence of Work-life Balance Practices on Performance of banking industry in Kenya. JKUAT.

Muthoka, M. K. (2016). Influence of Employee Relation Practices on Organizational Performance of Public Healthcare Sector in Kenya. Jomo Kenyatta University of Agriculture and Technology.

Mwangi, L., Boinett, C., Tumwet, E. \& Bowen, D. (2017). Effects of Work-life Balance on Employees' Performance in Institutions of Higher learning. A Case of Kabarak University. Kabarak University Journal., 4(2), 60-79.

Mwebi, M. \& Kadaga, M. (2015). Effects of flex time work arrangements on employee performance in Nairobi CBD Commercial Banks. International Journal of Novel Research in Marketing Management and Economics, 2(3), 111-121.

Ojo, I. S. (2012). Work-life Balance Policies and Practices: A case study of Nigeria female University students. European Journal of Business and Management, 6(12), 184-193.

Orogbu, L. O., Onyeizugbe, C.U., \& Chukwuemeke, D. N. (2015). Work-life Balance and Employee Performance in selected Commercial Banks in Lagos State. European Journal of Research and Reflection in Management Sciences, 3(4).

Osterman, P. (2001). Work/family programs and the employment relationship. Administrative Science Quarterly, 4(2), 681-700.

Sakthivel, D. \& Jayakrishnan, J. (2012). Work Life Balance and Organizational Commitment for Nurses. Asian Journal of Business Management, 2(5), 01-06.

Saunders, M.N.K., Lewis, P., \& Thornhill, A. (2009). Research Methods for Business Students (5th Ed). United Kingdom: FT Prentice Hall.

Slack, R.E., Corlet, S., Morris, R. (2014). Exploring Employee Engagement with (Corporate) Social Responsibility: A Social Exchange Perspective on Organizational Participation. Journal of Business Ethics, 127, 537.

Sullivan, C., \& Lewis, S. (2001). Home-based telework, gender, and the synchronization of work and family: perspectives of teleworkers and their co-residents. Gender, Work and Organisation, 8(2), 123-145.

Wainaina, L. W. (2015). Determinants of Organizational Commitment among Academic Staff in Kenya's Public and Private Universities. unpublished Phd thesis of Jomo Kenyatta University of Agriculture and Technology. 